\title{
Analysis of productivity and technical efficiency of cassava production in Ardo-Kola and Gassol Local Government Areas of Taraba State, Nigeria
}

\author{
A. A. GIREI ${ }^{1}$, B. DIRE ${ }^{1}$, R. M. YUGUDA ${ }^{2}$, M. SALIHU ${ }^{3}$ \\ ${ }^{1}$ Department of Agricultural Economics and Extension, School of Agriculture and Agricultural Technology, ModibboAdama University \\ of Technology, Yola, Adamawa State \\ ${ }^{2}$ Department of Business Education, School of Technology and Vocational Education College of Education Jalingo, Taraba State \\ ${ }^{3}$ Department of Agricultural Economics and Extension, Faculty of Agriculture, Federal University, Dutse, JigawaState
}

\section{Email address:}

agirejo@yahoo.com(A. A. Girei)

To cite this article:

A. A. GIREI, B. DIRE, R. M. YUGUDA, M. SALIHU. Analysis of Productivity and Technical Efficiency of Cassava Production in Ardo-Kola and Gassol Local Government Areas of Taraba State, Nigeria. Agriculture, Forestry and Fisheries.

Vol. 3, No. 1, 2014, pp. 1-5. doi: 10.11648/j.aff.20140301.11

\begin{abstract}
This study analyzed the productivity and technical efficiency of cassava production in Ardo-Kola and Gassol Local Government Areas of Taraba State. Data were collected from 115 respondents using a structured questionnaire covering 2010/2011 farming season. Inferential statistics were employed in the analysis of data collected. Maximum likelihood estimate (MLE) for all parameters of the stochastic frontier production function and the inefficiency model for the cassava farmers in the study area was employed in the analysis. The study reveals that, farm size is the most important factor of production having an elasticity coefficient of 0.492 indicating that, output of cassava production is inelastic. Indicating that, an increase of 5\% in farm size used in production of cassava, all things being equal; there would be a corresponding increase in the total output by $4.92 \%$. Similarly, herbicide has an elasticity coefficient of 0.315 and was statistically significant at $5 \%$. This implies that, an increase in the quantity of herbicide would increase the output by 3.15 percent. Hired labour has an elasticity efficiency of 0.783 and is positively related to the total output of cassava. A 5 percent increase in hired labour will bring about an increase in the level of output. Despites challenges faced by cassava farmers in the study area, the study concludes that, farmers involved in cassava production have more than average technical efficiency and this means there is opportunity to increase cassava production in the study area. Similarly, the cassava production was profitable in the area. The research recommended public private partnership (PPP) to sensitize and educate farmers to enable them benefit from the new innovations and technology that abound in the agricultural sector.
\end{abstract}

Keywords: Analysis, Productivity, Technical Efficiency, Cassava, Production

\section{Introduction}

It is widely acknowledged that the scope for agricultural production can be expanded and sustained by peasant farmers within the limits of existing resource base and available technology if farm productivity is raised by efficiency use of resources (Udoh, 2005).This exposition therefore, forms the fundamental point why the concept of farm efficiency has remained important economic study especially in developing agricultural economies like Nigeria, where resources are meager and opportunities for developing and adopting better technologies are dwindling. Efficiency analysis in agricultural production is generally associated with the possibility of farms producing a certain level of output from a given bundle of resources or certain level of output at least cost (Girei et al, 2013). According to (Simonyan et al, 2012), a production process may be technically inefficient if it fails to produce maximum output from a given bundle of inputs and is therefore operating beneath its stochastic production frontier. However, the analysis of allocative efficiency usually assumes that the farm firm seeks to optimize a profit maximization objective function subject to resource constraint. Resources are said to be efficiently allocated when the value of marginal product of each resource equals its price, Ibid.

The Nigeria's food sub sector parades a variety of crops 
ranging from cassava, yam, potatoes, rice, maize, beniseed, beans, guinea corn, groundnuts, tomatoes etc. the high concentration of cassava and its production in the study area constitute the basis for the selection of the crop in this study. However, (Onyemauwa, 2012) reported that, Cassava is almost a daily menu in Nigerian households especially in south eastern part of the country.

Cassava (Manihort esculentus) belongs to the family Euphorbiaceae (Cock, 1985). According to (Ross 1999), cassava originated from Brazil where it is the major stable food of the people. The cultivation and consumption of cassava is now worldwide with distribution throughout Africa, America, Europe, Asia and other part of the world (IITA, 2005). The World production of cassava root was estimated to be 184 million tonnes in 2002 (CBN, 2005). The majority of production is in Africa with 99.9 million tonnes. 51.5 million tonnes, were grown in Asia and 33.2 million tonnes in Latin America and the Caribbean. Almost 70 percent of the world production is concentrated in five countries that is, Nigeria, Indonesia, Thailand, Brazil and Congo Democratic Republic, Ibid.

Recognizing Nigeria's tremendous agricultural potentials, the Government has accepted the view that there should be a resolution to make agriculture the main stream of its economy. This is why the successive Governments had various agricultural revolutionary programmes, such as; the Nigerian Agriculture Cooperative and Rural Development Bank (2000), National Agriculture Development Fund (2002), Commodity Marketing and Development Company (2003) and the Presidential Initiative on Cassava Production (2002) among others. Despite government efforts in trying to improve agriculture and agricultural productivity, the demand for food is still at its alarming state; food is still imported; its productivity level still remains low compared with the result of the productivity in the past decades (FMARD, 2001).

It is against this background that this study is designed to provide answers to the following questions:

i. Is cassava production a profitable entreprise?

ii. Are cassava farmers technically efficient?

iii. Are cassava producers efficient in their resource utilization?

This study became necessary because of the potentials of the study area which was attributed to the suitability of its soil fertility and rainfall pattern which favours the cultivation of root crops. The study therefore, would be useful to the small holder farmers in effective resource utilization and policy formulations by the government/ policy makers especially when recommendations are adhered to as well as the cassava farmers. It will also help to increase the per capita income of the cassava farmers which subsequently would improve their standard of living. Hence, help enhance basis for further research in the field.

\subsection{Hypothesis}

$\mathrm{H}_{\mathrm{O} 1}$ The socio-economic characteristics do not affect the technical efficiency of cassava producers.
$\mathrm{H}_{\mathrm{O} 2}$ The various inputs used in cassava production do not affect cassava output.

\section{Methodology}

\subsection{The Study Area}

The study was carried out in Ardo-Kola and Gassol Local Government Areas of Taraba state. The state is located in the north east part of Nigeria and lies between latitude $6^{\circ} 30^{\prime}$ and $9036^{\prime} \mathrm{N}$ of the equator and longitude $9^{\circ}$ $10^{\prime}$ and $11^{\circ} 50^{\prime} \mathrm{E}$ of the Greenwich meridian (Taraba state Government Diary, 2008). The state has a land area of about fifty nine thousand four hundred square kilometers $\left(59,400 \mathrm{~km}^{2}\right)$, it shares a common boundary with Bauchi state in the north and Gombe state in the north east, Adamawa state in the east and Plateau state in the North West. Further, the state is bounded to the west both by Nasarawa and Benue state, while it shares an international boundary with Cameroon Republic to the south and south east (Taraba State Diary, 2008). It has a tropical climate marked by dry and rainy seasons. The rainy season starts in April and ends in October. The wettest months are August and September. The dry season starts in November and ends in April. The mean annual rainfall ranges from 800 $\mathrm{mm}$ in the north to over $2000 \mathrm{~mm}$ in the south. The mean minimum daily temperature recorded is $14.8^{\circ} \mathrm{C}$ and the mean maximum daily temperature recorded is $34.4^{\circ} \mathrm{C}$ (TADP, 2004).

The state is predominantly agrarian in nature, with about $80 \%$ of its inhabitants depending on subsistence agricultural practices mainly in food crops (TADP, 2004). The climate, soil and hydrology of the study area provide a conducive atmosphere for the cultivation of most staple food crops, grazing of animals, fresh water fishing and forestry. The rich alluvial tract of soil found in most part of the state makes Taraba state conducive and supportive for growing various foods and cash crops. The main farming system practiced in the area is either mono cropping or mixed cropping.

\subsection{Nature and Sources of Data}

The data for this study were obtained mainly from primary sources. The primary data was obtained from the cassava farmers in the selected wards in Gassol and Ardo Kola Local Government Areas of Taraba state. Questionnaire and personal interviews were used in the collection of the primary data needed from the cassava farmers. The primary data collected covered relevant aspect of the output and inputs used in the production process.

\subsection{Sampling Technique}

Purposive and random sampling techniques were employed in the selection of the sample farmers in the study area (Ardo Kola and Gassol LGA) using multi stage sampling procedure. In the first stage, two local government areas were purposively selected. Three 
wards were also purposively selected from each of the two local government areas based on their importance in cassava farming. A total of 18 villages were selected for the purpose of this study.

The second stage of sampling involved a simple random sampling of respondents from each of the selected local government areas and villages based on the list provided by the Root and Tuber Production Unit of the Taraba State Agricultural Development Programme (TADP). A total of 120 cassava farmers were randomly selected. The sampling procedure is presented in table 1.1 below.

Table 1.1:Ardo Kola and Gassol LGAs Wards and Villages to be sampled

\begin{tabular}{|c|c|c|c|}
\hline LGAs & Wards & Villages & No of farmers \\
\hline \multirow{10}{*}{ Ardo Kola } & \multirow{3}{*}{ JauroYinu } & Garin Mallum & 5 \\
\hline & & Sibre & 6 \\
\hline & & Jauro Yini & 6 \\
\hline & \multirow{3}{*}{ Iware } & Iware & 7 \\
\hline & & Pam petel & 5 \\
\hline & & JauroAngulu & 8 \\
\hline & \multirow{4}{*}{ LamidoBorno } & LamidoBorno & 8 \\
\hline & & Mallum & 6 \\
\hline & & Garin Ali & 7 \\
\hline & & MutumBiyu & 9 \\
\hline \multirow{8}{*}{ Gassol } & \multirow[t]{3}{*}{ MutumBiyu } & Doro & 7 \\
\hline & & Gunduma & 6 \\
\hline & & Namnai & 6 \\
\hline & \multirow[t]{3}{*}{ Namnai } & Badakosi & 5 \\
\hline & & Garin Abba & 4 \\
\hline & & SabonGida & 10 \\
\hline & \multirow[t]{3}{*}{ SabonGida } & Dinya & 9 \\
\hline & & SansaniGassol & 16 \\
\hline TOTAL & & & 120 \\
\hline
\end{tabular}

Source: Field survey, 2012.

Structured questionnaire was the main tool used in the collection of the primary data employed in the study. The researcher was assisted by the Extension workers of TADP and other trained personnel.

\subsection{Analytical Techniques}

Inferential statistics were employed in the analysis of data collected. The tool used was maximum likelihood estimate (MLE) for all parameters of the stochastic frontier production function and the inefficiency model for the cassava farmers in the study area.

\subsection{The Empirical Stochastic Frontier Production Model}

Stochastic Frontier Production Model was independently proposed by (Aigneret al.1977 and Meeusen and Van den Broeck, 1977). It employs a Cobb-Douglass production function to simultaneously estimate the random disturbance term $\left(\mathrm{V}_{i}\right)$ which is outside the control of the production unit and the inefficiency effects $\left(\mathrm{U}_{i}\right)$ as proposed by Batesseet al. (!996). The stochastic frontier production function used is specified as follows:

$\log Y_{i}=\beta 0+\beta_{1} \log X_{1}+\beta_{2} \log X_{2}+\beta_{3} \log X_{3}+\beta_{4} \log X_{4}+$ $\beta_{5} \log \mathrm{X}_{5}+\beta_{6} \log \mathrm{X}_{6}+\mathrm{V}_{i}-\mathrm{U}_{i}(4)$
Where:

$\mathrm{Y}_{i}=$ Output of cassava

$\mathrm{X}_{1}=$ Farm size (ha)

$\mathrm{X}_{2}=$ Cassava cuttings $(\mathrm{kg} / \mathrm{ha})$

$\mathrm{X}_{3}=$ Hired labour (mandays)

$\mathrm{X}_{4}=$ Fertilizer $(\mathrm{kg} / \mathrm{ha})$

$\mathrm{X}_{5}=$ quantity of herbicides (litres)

$\mathrm{X}_{6}=$ Expenses on ploughing by tractor and animal draught (Nigerian Naira)

$\mathrm{V}_{i}=$ Random noise (white noise) $\mathrm{N}\left(\mathrm{O}, \delta^{2} \mathrm{v}\right)$

$\mathrm{U}_{i}=$ Inefficiency effect which are non-negative, half normal distribution, $\mathrm{N}\left(\mathrm{o}, \delta^{2} \mathrm{u}\right) \delta^{2}=\delta^{2} \mathrm{~V}+\delta^{2}+\mathrm{u}$

The technical efficiency of cassava production for the $i^{\text {th }}$ farmer, defined by the ratio of observed product as to the corresponding frontier production associated with no technical inefficiency was expressed as;

$\mathrm{TE}=\operatorname{Exp}\left(\mathrm{U}_{i}\right)$ so that $\mathrm{O} \leq \mathrm{Te} \leq 1 \ldots \ldots \ldots$

The inefficiency model is defined by,

$\mathrm{U}_{i}=\delta 0+\delta_{1} \mathrm{Z}_{1}+\delta_{2} \mathrm{Z}_{2}+\delta_{3} \mathrm{Z}_{3}+\delta_{4} \mathrm{Z}_{4}+\delta_{5} \mathrm{Z}_{5}$

Where

$\mathrm{U}_{i}=$ Inefficiency effect

$\mathrm{Z}_{1}=$ Gender of the respondent $(1=$ female, $2=$ male $)$

$\mathrm{Z}_{2}=$ Age of the farmers (years)

$Z_{3}=$ Literacy level (years)

$\mathrm{Z}_{4}=$ Family size (Number of people in farmer's household)

$Z_{5}=$ Visits of Extension offices $(1=$ contacted, $0=$ otherwise)

$\delta_{0}-\delta_{5}=$ Are parameters to be estimated.

The maximum likelihood estimate (MLE) for all parameters of the stochastic frontier production function and the inefficiency model defined above and the technical efficiency were obtained using programme Frontier 4.1 computer programme (Coelli, 1994; Ajibefun, 1998; Girei, et al, 2013).

\section{Results and Discussion}

\subsection{Resource Productivity}

The result in table 1.2 shows the maximum likelihood estimates parameters of the stochastic frontier production analysis of cassava farmers in the study area. It shows that most of the estimated coefficients of the parameters of production function are positive except expenses on ploughing. This indicates that cassava output increases as the quantity of each variable input increases. All the inputs used in the model are statistically significant 1 and 5 percent level of significance except expenses on ploughing.

From the table, farm size is the most important factor of production having an elasticity coefficient of 0.492 indicating that, output of cassava production is inelastic. An increase of $5 \%$ in farm size used in production of cassava, all things being equal; there would be a corresponding increase in the total output by $4.92 \%$. This implies that land is a significant factor associated with variation in cassava production. This also, agrees with the findings of (Eyo and 
Igben 2002, Maurice et al.2005). Cassava cuttings have an elasticity efficiency of 0.726 and are positively related to total output of cassava. A $5 \%$ increase in the quantity of cassava cuttings would bring about a corresponding increase of cassava output per hectare.

Table 1.2: Maximum Likelihood Estimate of the Parameters of the Stochastic Frontier Production Function of Cassava Farmers

\begin{tabular}{|c|c|c|c|c|}
\hline Variable & Parameters & Coefficient & t-ratio & $\begin{array}{l}\text { Standard } \\
\text { error }\end{array}$ \\
\hline \multicolumn{5}{|c|}{ Production factors } \\
\hline Constants & $\beta_{0}$ & 0.1784 & 6.715 & 0.0265 \\
\hline Farm Size $\left(\mathrm{X}_{1}\right)$ & $\beta_{1}$ & 0.4929 & $1.809 * *$ & 0.2725 \\
\hline Seed or & & & & \\
\hline $\begin{array}{l}\text { Cassava } \\
\text { cuttings }\left(\mathrm{X}_{2}\right)\end{array}$ & $\beta_{2}$ & 0.7264 & $2.014 * *$ & 0.3605 \\
\hline $\begin{array}{l}\text { Hired Labour } \\
\left(\mathrm{X}_{3}\right)\end{array}$ & $\beta_{3}$ & 0.7839 & $8.238^{*}$ & 0.9515 \\
\hline $\begin{array}{l}\text { Herbicides } \\
\left(\mathrm{X}_{4}\right)\end{array}$ & $\beta_{4}$ & 0.3157 & $2.610 * *$ & 0.1209 \\
\hline Fertilizer $\left(\mathrm{X}_{5}\right)$ & $\beta_{5}$ & 0.2627 & $2.956^{*}$ & 0.8798 \\
\hline $\begin{array}{l}\text { Expenses on } \\
\text { Ploughing }\left(\mathrm{X}_{6}\right)\end{array}$ & $\beta_{6}$ & 0.6037 & -8.348 & 0.7231 \\
\hline \multicolumn{5}{|c|}{ Inefficiency Effect } \\
\hline Constant & $\delta_{0}$ & -0.2814 & -2.8163 & 0.9993 \\
\hline Gender $\left(Z_{1}\right)$ & $\delta_{1}$ & -0.6345 & $-6.3613^{*}$ & 0.9975 \\
\hline $\begin{array}{l}\text { Age of farmer } \\
\left(Z_{2}\right)\end{array}$ & $\delta_{2}$ & -0.2511 & $-9.1372 *$ & 0.2748 \\
\hline $\begin{array}{l}\text { Literacy level } \\
\left(Z_{3}\right)\end{array}$ & $\delta_{3}$ & -0.5257 & 3.128 & 0.7680 \\
\hline $\begin{array}{l}\text { Family size } \\
\left(Z_{4}\right)\end{array}$ & $\delta_{4}$ & -0.1119 & $-1.487 * *$ & 0.7528 \\
\hline $\begin{array}{l}\text { Extension } \\
\text { Contact }\left(Z_{5}\right)\end{array}$ & $\delta_{5}$ & -0.5620 & $-2.916^{*}$ & 0.1926 \\
\hline \multicolumn{5}{|c|}{ Variance Parameter } \\
\hline Sigma squared & $\delta^{2}$ & 0.8606 & $1.8107 * *$ & 0.4752 \\
\hline Gamma & $\Gamma$ & 0.8564 & $2.2172 * *$ & 0.3862 \\
\hline
\end{tabular}

Source: Computer output from Frontier 4.1

* Significant at $1 \% ; * *$ significant at $5 \%$ level

Productivity is the index of the ratio of output to input in the production process. Productivity is synonymous with resource use productivity. The computation of this important productivity statistics include the elasticity of production $(\varepsilon \mathrm{P})$, return to scale (RTS), marginal rate of technical substitution (MRTS), Average Product (AP), Marginal Product (MP).

This agrees with (Olayide and Heady, 1982) who stated that agricultural productivity can be increased through increase in the quantity of a particular input. Herbicide has an elasticity coefficient of 0.315 and was statistically significant at 5 percent. This implies that, an increase in the quantity of herbicide would increase the output by 3.15 percent.

Fertilizer is one of the most important factors with an elasticity coefficient of 0.262 and is statistically significant at $1 \%$. Fertilizer plays an important role in increasing and improving agricultural output per hectare. Expenses on ploughing were statistically insignificant because it have a negative sign (-0.834). This does not mean that ploughing of land for cultivation was not important but it could be that it has been underutilized. The result of the inefficiency effect indicates that the coefficients of gender, age of farmers, literacy level, family size, and contact with extension workers have the expected negative signs and that means that the variables have a positive effect on efficiency.

Hired labour has an elasticity efficiency of 0.783 and is positively related to the total output of cassava. A 5 percent increase in hired labour will bring about an increase in the level of output. The use of hired labour is a major feature of agricultural production in Africa where mechanized farming is very low. Amaza et al. (2006) revealed that labour is a significant variable in agricultural production.

\section{Conclusion}

The study concludes that, farmers involved in cassava production have more than average technical efficiency and this means that, there is opportunity to increase cassava production in the study area. Similarly, the cassava production was profitable in the area. Hence, the study would serve as a reference point for other researchers to conduct further research and to also guide government and other policy makers in the formulation of future policies and plans for increase productivity, income and wealth generation in the study area and the country at large. The following recommendations are proffered based on the finding of the study; Public Private Partnership (PPP) should be explored by government so as to help the education of farmers with regard to new technology and innovations. The provision of agricultural inputs such as fertilizer should be liberalized so as to allow the target group to access fertilizer. Also, the voucher system of fertilizer procurement, already in practice in some states, should be extended to other farm inputs so as to boats agricultural production. Machines for planting cassava cuttings and harvesting of roots should be provided so as reduced the drudgery involved in cassava production which will ultimately improve farmer's technical efficiency. Financial institutions and the private sector should be encouraged to establish cottage type processing facilities in the study area that will include storage and packaging facilities so as to add value to cassava produced so as to meet the export specification of cassava product.

\section{References}

[1] Ajibefun, I. A., and Abdulkadri, A. (1999). An Investigation of Technical Inefficiency of Production of Farmers under the National Directorate of Employment in Ondo State, Nigeria. APP Economics Letters, 6, 111-114.

[2] Amaza, P.S and Maurice, D.C (2005): Identification of factors that influence Technical Efficiency in Rice - based production system in Nigeria. Paper presented at the workshop in Politics and strategies for promoting rice production and food security in Sub - Saharan Africa $7^{\text {th }}-$ $9^{\text {th }}$ Nov. 2005 COAONOU. 
[3] Aigner, D.J., Lovell, C.A.K., Schmidth, P.J. (1977). Formulation and estimation of stochasticfrontier production models. J. of Econometrics, 6(1), 21-38.

[4] C.B.N (2005): Central Bank of Nigeria Statistical Bulletin, Nnanna, J.O, Adewuyi, B.S, Madi, N.O (eds) CBN Statistical Bulletin 16:

[5] Coelli, T.J. (1994). A guide to frontier version 4.1: A computer program for stochastic frontierproduction and cost function estimation. Mimeo. Department of Econometric,University of New England Armiade.

[6] Cork, J.H (2005): New Potentials for Neglected Crop. West View Press, Bouldex. COUSA. P.10.

[7] Eyoh, E.O. and S.I. Igben (2002). Agricultural Economics: An Introduction to Basic Concepts and Principles. Best Print Business Press, Uyo, Nigeria, pp238.

[8] FMARD (2001): Nigeria Rural Development Sector Strategic Main Report. Federal Ministry of Agriculture and Rural Development, Abuja, Nigeria

[9] Girei, A. A. and Dire, B. (2013). Profitability and technical efficiency among the beneficiary crop farmers of National Fadama II Project in Adamawa State, Nigeria. Net Journal of Agricultural Science Vol. 1(3), 87 - 92.

[10] IITA (2005). Standard for cassava products and Guidelines for Export. International Institute for Tropical Agriculture (IITA), Ibadan.

[11] Maurice, D.C. Amaza, P.S. and Tella, M.O. (2005): Analysis of Technical Inefficiency in Rice - based cropping pattern among dry season farmers in Adamawa state, Nigeria. Nigerian Journal of Tropical Agriculture 7(1): 125 - 130.

[12] Meeusen, W. and J. van den Broeck, 1977. Efficiency Estimation from Cobb-Douglas Production Functions with Composed Error. In:Econ., 18: 435-44

[13] Olayide, S.O. and Heady, E.O. (1982): Introduction to Agricultural Production Economics. University of Ibadan, Press Ibadan, Nigeria. PP $233-238$.

[14] Onyemauwa, C. S. (2012).Analysis of Women Participation in Cassava Production and Processing in Imo State, Southeast Nigeria. Agricultural Tropical ET Subtropical ,45 (2) $72-77$

[15] Simonyan, J. B., Olukosi, J. O., Omolehin, R. A. and Atala, T. K. A., (2012).Productivity and Technical Efficiency among Beneficiary Farmers of Second NationalFadama Project in Kaduna State, Nigeria. American Journal of Experimental Agriculture 2(1): 102 - 110

[16] Taraba State Government Diary (2008): Taraba State Official Diary, Government Printer Jalingo, Nigeria pp $25-$ 29.

[17] Udoh EJ, 2006. Technical inefficiency in Vegetable Farms of Humid Regions: An Analysis of Dry Season Farming by Urban women in South- South Zone, Nigeria. J AgricSocSci, $1(2): 80-85$

[18] Udoh, E.J., 2005. Technical Inefficiency in Vegetable Farms of Humid Region: An Analysis of Dry Season Farming byUrban Women in South South Zone, Nigeria. J. Agric. Soc. Sci., 1: 80-5 